Archaeological Journal

\title{
English Wrought Iron-Work from the Thirteenth Century
}

\section{H. Longden}

To cite this article: H. Longden (1890) English Wrought Iron-Work from the Thirteenth Century, Archaeological Journal, 47:1, 130-139, DOI: $10.1080 / 00665983.1890 .10852416$

To link to this article: http://dx.doi.org/10.1080/00665983.1890.10852416

曲 Published online: 15 Jul 2014.

Submit your article to this journal $๘$

Q View related articles $\asymp$ 


\section{ENGLISH WROUGHT IRON-WORK FROM THE THIRTEENTH CENTURY.}

By H. LONGDEN.

I propose, in the following paper, to consider only wrought iron-work that is connected with buildings, and to illustrate it, as far as possible, by references to existing examples, supported by illuminated MSS. and by records. The iron-work of armour and weapons is a subject requiring special knowledge, such as the late Mr. Burges possessed in an eminent degree, but we are not concerned with work of this kind now, and cast iron, though of much interest, is comparatively modern, and does not fall within the scope of the present paper.

The use of wrought iron-work for purposes of security was fully developed earlier than the thirteenth century, and in the illuminations in one of the Cottonian MS., about 1125, fine hinges and lock plates are shown on doors. The hinges are of the strap form, richly worked out at the ends into scrolls and finishing in leaves. Hinges with what is called the $\mathrm{C}$ scrolls are very characteristic of this period. The iron-work was much spread over the doors to protect and strengthen the wood of which the doors were made, and no doubt the usefulness of these widespreading hinges had much to do with their general adoption in buildings of importance. The work appears to have been done at the place and during the time the structure was being erected. The artificers in all trades connected with a building gathered together while one of importance was being erected, and stayed there as

Read in the Architectural Section at the Annual Meeting of the Institute Norwich, August 10th, 1889. 
long as there was work for them; this might be for years in the cases of the great castles and churches which were being set up in all parts of the country. Good examples of the work of the twelfth century are to be found on the doors of the hall of Merton College, Oxford, or on those in the Cloisters of Durham Cathedral. Sometimes this early work has been altered, having apparently been moved from its original position, and adapted to a new place; but the character of the ironwork of this time is unmistakeable.

In the thirteenth century the same kind of iron-work prevailed, but it became richer and more elaborate, until it may be said to have culminated in such work as the grille over Queen Eleanor's tomb in Westminster Abbey. A peculiar treatment of flowers and leaves sprang up in This century, in imitation of the ornaments which were being carved in wood or stone, or painted on walls, or in stained windows. Swages, or dies made of iron, were carved out, into which the hot iron was beaten, thus taking the impress of the carved flower or leaf by the same kind of process as that by which a seal is made, except that the hot iron is laid upon the swage or die and beaten into it. This amount of force is necessary to produce the required impression, as the iron is too hard and tough to take the impression without it. These flowers and leaves are generally used at the ends of scrolls or branches, though sometimes, as at Tunstead Church in Norfolk, they are welded upon the main strap of the hinge, and turned back to show the modelling of the ornament. Any number of these repetitions may be made by taking due care, and it might be thought that this foreshadowed the modern commercial way of making things by the hundred or the thousand. If applied in the modern way, this manner of making flowers and leaves would be exposed to this reproach, but as the quantity made could only be very small, and the effect sought for could only otherwise be got at very great cost in carving out the ornaments, we may approve of it. I prefer, however, the purely hammered or chiselled work to this, as more legitimate smith's work. On the doors of the Cathedral Grammar School of Norwich are some fine hinges of this kind. 
Other fine specimens of the work of this century are in the crypt of Wells Cathedral. An iron door, which was made as a strong door to the Treasury, is there preserved. It is made of slabs of iron nailed to an oak frame-work, and liberally braced across with hinges and diagonal cross-straps, stiffening the door in the best way known at the time. This is not an iron-plated door, but an iron door, it is in fact, a "safe " door of the time, and is an uncommon instance. It must be remembered that the slabs of which this door is formed were all beaten out of lumps of iron, and that iron was not then made as now, in plates, bars, or rods, but that whether a thin plate, a square bar, or a round rod was needed, the lump of iron had to be heated and drawn out on the anvil at great expenditure of time and labour. Much of the charm of old work arises from the irregularity of the shapes, never quite round, or square, or flat, which the iron took, and we miss this in the neat and mechanically finished work of the present time.

I find that the principal smith who worked at the Palace of Westminster in the years 1293 and 1294, in the reign of Edward the First, was paid as highly as the principal mason, 6d. a day, - while the apparitor or foreman was only paid 3s. 6d. a week, or 7 d. a day. From this it appears that the skilled smith's labour was as highly paid for as any other labour, and nearly as highly as the foreman's labour. A painter, Master Walter, had 14d. a day, and other painters had from $7 \mathrm{~d}$. to $3 \mathrm{~d}$. a day. Master Walter would no doubt design the painted decorations, which were very elaborate, containing figures, and he would paint the most difficult part of them, the other painters helping him according to their ability.

The doors to the Chapter House of York have good iron-work of this time. The greater refinement in design and workmanship is shown in the smaller matters of ironwork. At Tickencote Church, in Rutlandshire, is a ring-handle to a door with a shield shaped escutcheon, cut out of plate-iron, edged all round with cusped tracery, and divided lengthway into five long cusped divisions. This, though simple, is as refined in design as any lockplate of later times.

The domestic work of which we find traces in MS. is 
very plain. In a MS. at the Bodleian in illustration of the coronation of Edward the First, in preparation for the feasting, a grid-iron stands on four feet over a fire on the ground out-of-doors, and the cooks are turning the meat upon it with a curious double hook, A great iron flesh-pot is boiling over a fire in a narrow arched fire-place, and the pot seems to have no other support than resting on the fire. These arrangements are much ruder than we shall find later.

In the fourteenth century the development of the iron hinges continues. The arrangement of the design did not = change much, but the character of the ornament becomes more naturalistic and the work is done principally by the ¿ hammer and not in swages. At S. Margaret's Church at Tley-next-the-Sea in Norfolk, is a specially good example Fo firon-hinges, and, though they are much decayed from of the effect of the sea-air, I found, on examining them m recently, traces of the original gilding at the bottom of punched star-shaped ornaments in the straps of the hinges.

Grilles to cover the windows in houses are larger and resemble some which may still be seen in Italy and Germany. There was one at Yanwath Hall in Westmoreland, which I found on a recent visit has disappeared, and in one of the Bodleian MS. a grill is shown in the form of a cage fixed over a window. It is made of horizontal bars of round iron with loops carried inward or towards the windows, through which upright bars are laced. The ends of all the bars, both upright and horizontal, are turned, inward and leaded into the wall, outside the opening for the windows, thus forming a complete cage and protection to it.

In domestic work there was a considerable development. In another of the Bodleian MS. two arched stove fire-places have dogs in them, which is the earliest date at which I find them. These are of simple forms, but they generally end in scroll tops, sometimes beaten into leaves. We must however remember that the scribe loved a flourish with his pen, or the painter with his brush, and that these little flourishes in drawing a utensil so liable to be knocked about as a fire-dog, may be chiefly due to the fancy of the draughtsman. In the fronts of these dogs are often shown hooks for spits, and, in this illumination a fire is shown on 
the ground, out of doors, with a couple of fire-dogs acting simply as bearers of standards for the spit, which is being turned by a boy, one of "ye laddes of ye kychyn," who sits at one end of the spit, and looks quite uncomfortably near the fire. Sometimes in the stone arched fire place an iron pot is shown hanging over the fire on a rack-hook, to raise or lower the pot, just such as may be seen to this day in the fire places in Surrey and Sussex, where faggots are still burnt on the hearth and fire-dogs used. A tradition of this plan of boiling the pots also remains in Yorkshire and the northern counties, where great coal fires have long been employed, in a fixed bar running from side to side horizontally over the fire, on which a sliding rack-hook to hold pots is fixed, so that the place for the pot can be changed both vertically and horizontally.

The greater refinement of work in the fourteenth century led to much neat and ingenious iron work. I have found a note of a bunch of keys which were slung on a ring, and fitted closely side by side of one another, varying in length, so that when put together they formed almost a solid mass of iron and took up the least possible room. These belonged at the end of last century to Sir John Fenn of East Dereham. Precisely the same things were made in Roman times.

There are very interesting notes in the accounts of the ancient Palace of Westminster about the cost of iron and of working it, from which I give some extracts.

1331.

5th EDWARD III.

Aug. 3. To Robt. of St. Alban's, for 3 cwt. of Spanish iron, for bars and iron-work at the east gable at $4 \mathrm{~s} .8 \mathrm{~d}$. per cwt., $13 \mathrm{~s}$.

To Walter de Bury, smith, for making the iron bars at 4s. per cwt., $12 \mathrm{~s}$.

Aug. 11. To Robt. of St. Alban's, for 2 cwt. of iron, 9s. 4 d.

To W. de Bury, for working the said iron, almost one half of which was wasted in the fire, 8s.

Aug. 31. To Robt. of St. Alban's for $3 \mathrm{cwt}$. of iron, 15s. $2 \mathrm{~d}$. 
To Walter the smith, of Bury, for making the iron into bars, almost half being wasted, $13 \mathrm{~s}$.

May 17. To Walter de Bury, for an iron bar 12 feet long, weighing 3 quarters 10 pounds, at $1 \frac{1}{2} \mathrm{~d}$. per lb., made out of his own iron, to strengthen a marble column, and keep in its place under the great form, $10 \mathrm{~s}$. $7 \frac{1}{2} \mathrm{~d}$.

Nov. 2. To Walter de Bury, the smith, for making two iron bars called " tirauntz," fifteen feet long each, out of seven hundred weight of iron de Baton, received by order of the Treasurer out of the stores in the Tower; and for work upon the said bars, for the purpose of strengthening and keeping in their places the "Moynells" (mullions of the window), in the east gable, three-fourths of the iron being wasted in the fire because of its weakness, $£ 18$ s.

1351. June 20. For sixty-one "sondlets" bought of Master Andrew the smith, for the east window of the Chapel, weight 51 lbs. at 2 d. per lb., 8s. 6 d.

July 25. To Simon le smyth for 100 nails to fasten in the glass, $9 \mathrm{~d}$.

1358. To Master Andrew, the smith, for two " ridells" (possibly curtain rods), for the chapel of S. Mary, and two iron bars for the windows in the chancellary, $12 \mathrm{~s}$.

To the same for an iron stand for the image of St. Stephen, $£ 16$ s. 8 d.

To the same for 3 pairs of ornaments for the stalls, $3 \mathrm{~s}$.

1365. (Ferret cerur') To Master Stephen Smith "pro una cerur' cro' 2 clav' 1 par garnettor 2 ligatior ad 4 bolt et 160 clav' gross rivat' et oninib' stannatis," bought for a certain door newly made in the King's garden, "in grosso," $£ 3$ 3s. 4d.

To the same, for three great iron bars and ten lesser bars, for the windows of the chamber of the beforementioned tower, near the King's garden, weight 2,941 lbs., $£ 27$ 8s. 2d.

To the same for 260 nails, bought to repair the bridge of the (wool) staple and palace, "pro emendatione pont' stapulæ et palac'," weight, $79 \frac{1}{2}$ lbs at 2 d. per lb., 13s. 3 d.

To the same "pro 2 cass' ferr'," for the glazing of a window in the Great Hall, six pair of garnetts "pro prædict' armorial, infra prædictum capellam," and two iron plates for two doors in the King's Treasury in Westminster Abbey, 14s. 4d. 
I find some things worthy of notice in these extracts. One as to the quality of the iron. Walter de Bury wasted a considerable part of the iron in working it. This shows that the iron was badly made, or that he was a careless smith, and "burnt" his iron (by which is meant so overheating the iron that its ductility is destroyed), or both. there is no note of waste in the work made out of his own material.

"Spanish" iron seems to have been good, and "iron de baton," or rod iron, from the Tower, not to have been so. I have sometimes thought that all old iron was good, as it was necessarily smelted with charcoal, a process still used, at vastly increased cost when the toughest iron is needed. But I suppose we must conclude that the old iron-work left to us was made of good material, and that the bad has clecayed. We know that stone work was not invariably good, and that there was what we should now call "scamping" in building; so I imagine in the making of iron there was good and bad work.

In the complete set of iron-work for a door, paid for to Stephen Smith in 1365, we find "et omnibus stannatis," by which it appears that the work was tinned, which is a great protection from rust in our damp climate.

In the fifteenth century iron-work again changed in character. The richly panelled and mullioned doors did not allow of the same elaboration of hinges. This was partly accounted for by the necessity for protection being less, and partly by the architectural style, which covered every part of a building with surface ornament. The hinges are often mere straps passing under the tracery of the doors, and have sometimes pierced ornaments in them, or a little enrichment at the ends, but the simple strap form is only slightly departed from. In a sort of revenge, the locksmith grew into an important personage, in whom was probably merged the smith proper. Beautiful locks were now made, in which the iron cases were covered with rich patterns, pierced out of plate-iron, and one laid over the other, of exceedingly elaborate traceried designs, which were usually framed, or divided into panels by twisted work like rope. As the locksmith with his vice and small tools, chisels, drills and files, had come into the field, he began sculpture in iron, of which. 
we have only few and rude examples up to this century, and he produced coats of arms with supporters, flowers, and other applied ornaments, done with wonderful spirit and finish, and showing what care and skill can do with an unsuitable material. There is a fine lock of this kind in Beddington Manor, in Surrey, and there are door handles in Lincoln Minster, showing how red velvet, cloth or leather, was put underneath the pierced iron-work.

Railings round tombs were made of square bars, spear or lance-pointed, with heads imitating halberds or other weapons, with rails either cut out for the upright bars to pass through them, or imitating a cable by twisting two round rods and putting in the upright bars at regular intervals as the twist was made-a needlessly difficult thing to do with regularity. Sometimes a rich band of plate iron-work with battlements and inscriptions, or with raised applied letters, ran round near the top of the railing. Round Bishop Beckington's tomb in Wells Cathedral was a fine railing of this character. The Bishop died in 1464 , and the tomb was erected not long after this date. In Dugdale's account of Old St. Paul's, with Hollar's engravings, is a representation of St. Erkenwald's altar, which stood behind the High altar, and this altar, over which the Feretory of St. Erkenwald stood, was surrounded by a railing very similar to that I have described.

There are some good iron fire-dogs in the Vicar's Close Common-Hall at Wells, which seem to belong to this century. They have rather rudely sculptured rams' heads at the top, with rings in them, by which the dogs can be moved; the shafts are octagonal, with a finely moulded collar in the centre, and the foot is square and rather clumsy. Brass had begun to come into use for this kind of work, and the smith was gradually being pushed out of his place among the workers in the industrial arts.

In the sixteenth century hinges became quite small, and spread up and down the styles of the doors, having chamfers of an ingenious kind, which suggested the strapwork so much in use then as an ornament. Sheet iron was cut out into ornamental forms and used for making lanterns, the work of the smith being in full decadence.

The grates at Haddon Hall, which are simple baskets, or, when dogs are used, have the ornamental parts VOL. XLYII 
applied in brass, are some of the earliest attempts to make grates for burning coal, which has for centuries been worked in that part of England.

The date of the curious iron hinges on the North Porch door of Dartmouth Church, consisting of sprays of oakwork nearly covering the door, with two great leopards stretching right across the door and over the oak-work, is disputed, but I am inclined to put them in the sixteenth century.

In the seventeenth century came a great revival of iron-work in a very characteristic style. Sir Christopher Wren used this metal in his buildings, and in St. Paul's are some of the best examples of his manner. The gates, both outside and inside, the grilles in the openings in the stalls, and some railing to the staircase in the south-west tower show the great ability and freedom with which Wren used iron. Tijou, a Frenchman, directed this work, and other men worked under him, as the following note shows from the accounts of Trinity College, Cambridge, between March, 1691, and February, 1692 :-_Paid to Mr. Partridge, the London Smith, in part for gate and other work $£ 80$ 00. 00. Paid to $\mathrm{Mr}$. Partridge in full, for the three iron gates in the Cloyster and Iron Railes in the stair case, besides $£ 80$ formerly paid £320 00. 00."

From this we see that the modern system of making wrought iron work, away from the building for which it is intended, had become established, and that Wren's great works at St. Paul's, and his other buildings, had established a school of iron-workers in London. Good work was, however, made elsewhere, but it gathered to centres, and the travelling or nomad smith has disappeared.

The famous screens at Hampton Court are said to have been made by Huntington Shaw of Nottingham, and we have seen in our excursions from various centres ironwork in All Saints' Church, Derby, a curious iron temple in Melbourne Hall grounds, the gates of Chirk Castle, fine gates and screens in Wrexham Church, and the rich hanging pieces to the two fine brass candelabra in Melton Mowbray Church, "The gift of Rich. Gregory of Burton Lazars in this parish, Gentleman, 1746."

This brings us almost to our own time. At the end of 
the last century ornamental smith's work died down again, and the development of iron-founding-which is an excellent thing in its place, and has an interesting historyfor the time checked the smith's art.

It is as a part of the great revival of the arts, in connection with architecture in our times, that iron-work has been revived, and in this, as in so many of the art industries, we owe a deep debt of gratitude to Augustus Welby Pugin.

It is often said that old work is better than new. This is not true if the latter is set about in the old way, and after study of the reasons for the excellence in the former. The ordinary needs of agriculture and of manufacture have kept alive the race of smiths, and there are among them many skilful men, with a love for their art, who, if they are shown the reason of the excellence of the old work by anyone who enters into it, will set themselves to rival it, or, if possible, to surpass it. The northern nations of Europe are smiths by instinct, and we have not lost the instincts of our forefathers in this particular any more than in other ways. Let due opportunities be given and $\mathrm{I}$ will answer for a response being made to them. 